Int. J. Electrochem. Sci., 15 (2020) 6060 - 6090

\title{
Transport and kinetics in electrocatalytic thin film conducting polymer biosensors: bounded diffusion with Michaelis-Menten kinetics incorporating general inhibition effects
}

\author{
Michael EG Lyons \\ School of Chemistry and AMBER National Centre, University of Dublin, Trinity College Dublin, \\ Dublin 2, Ireland. \\ E-mail: MELYONS@tcd.ie
}

doi: $10.20964 / 2020.07 .01$

Received: 4 March 2020 / Accepted: 26 April 2020 / Published: 10 June 2020

In this paper we discuss the problem of discussing the transport and catalytic reaction kinetics at redox enzymes immobilized within an electronically conductive polymer matrix where the effect of inhibition is specifically considered in the rate equation. Here the reaction kinetics are not of the simple MichaelisMenten type. WE describe a mathematical procedure based on the recently developed technique developed by Akbari and Ganji which facilitates a full analytical solution of the boundary value problem which is valid over an extended substrate concentration range. Closed form expressions for both the substrate concentration in the film and the steady state amperometric current response are presented. 10 limiting kinetic cases are identified and discussed.

Keywords: Amperometric polymer sensor modelling; Michaelis-Menten kinetics with inhibition; Transport and kinetics in chemically modified electrodes; redox enzyme kinetics. Reaction/diffusion equations.

\section{$\underline{\text { FULL TEXT }}$}

(C) 2020 The Authors. Published by ESG (www.electrochemsci.org). This article is an open access article distributed under the terms and conditions of the Creative Commons Attribution license (http://creativecommons.org/licenses/by/4.0/). 